\title{
Condition factor and diet of Chrysichthys nigrodigitatus and Chrysichthys auratus (Siluriformes: Bagridae) from Aiba Reservoir, Iwo, Nigeria
}

\author{
Oluwatosin Ebenezer Atobatele ${ }^{1}$ \& Alex Obih Ugwumba ${ }^{2}$ \\ 1. Department of Biological Sciences, Bowen University, P.M.B. 284, Iwo, Osun, Nigeria; tosine_ben@yahoo.com \\ 2. Department of Zoology, University of Ibadan, Ibadan, Nigeria; oa.ugwumba@mail.ui.edu.ng
}

\author{
Received 21-VII-2010. C Corrected 01-II-2011. Accepted 04-III-2011.
}

\begin{abstract}
Chrysichthys nigrodigitatus and C. auratus are important, highly valued and threatened freshwater species. To contribute with their ecological knowledge, the condition factor and diet of these two congeneric species were studied between April 2005 and April 2006. Food items of fish were evaluated by occurrence and numerical abundance methods, and the possible changes among sexes, seasons and sizes were considered. Results showed that generally $C$. nigrodigitatus were better conditioned than $C$. auratus. The males of $C$. nigrodigitatus and females of $C$. auratus were in better condition than their respective opposite sex throughout the year, and during the wet season compared to the dry. The food items of C. nigrodigitatus and C. auratus were similar and comprised twelve species belonging to five groups: Insecta (three species), Crustacea (five species), Arachnida (one species), Rotifera (one species) and Mollusca (two species). Other food items included fish scales, unidentified green eggs, plant parts, detritus and sand. Insecta and Crustacea dominated the food items in both species. For $C$. nigrodigitatus, insect consumption increased with fish size, while Crustacea items decreased (from $89.59 \%$ for $8.1 \mathrm{~cm}-12.0 \mathrm{~cm}$ size class to $1.58 \%$ for $20.1 \mathrm{~cm}-26.0 \mathrm{~cm}$ size class). However, while $C$. auratus smaller sized fish preferred Crustacea $(98.72 \%$ for $8.1 \mathrm{~cm}-12.0 \mathrm{~cm}$ size class), larger sized fish had both groups in relatively similar amounts. Schoener Overlap Index for both species and between seasons is 1.00. Diet breadth ranged from 0.00-1.47 for C. nigrodigitatus and 0.00-1.32 for C. auratus. Food Richness ranged from 0.00-1.44 for both species. Gut Repletion Index for C. nigrodigitatus and C. auratus are $76.39 \%$ and $76.27 \%$ respectively. Although, there is considerable similarity and overlap in the utilization of food resource for both coexisting species, condition factor and feeding behavior suggest strategies to reduce intra- and interspecific competition. Rev. Biol. Trop. 59 (3): 1233-1244. Epub 2011 September 01.
\end{abstract}

Key words: Chrysichthys, condition factor, feeding behaviour, competition, Aiba Reservoir.

The Silver Catfish, comprising two congeneric species (Chrysichthys nigrodigitatus and C. auratus, are economically important fish species of Aiba Reservoir, Iwo. Idodo-Umeh \& Victor (1991) reported that $C$. nigrodigitatus and $C$.auratus longifilis were the principal species of the bagrid catfishes in River Ase, Southern Nigeria. The latter authors also reported $C$. nigrodigitatus to be a rainy season species, while $C$. auratus longifilis was abundant in both dry and rainy seasons. $C$. nigrodigitatus is an important, highly valued and ubiquitous freshwater fish of Nigerian inland waters and is sought after for its flavor and chemical composition (Akinsanya et al. 2007, Saliu 2008, Olarinmoye et al. 2009). The acute reduction in the population of this species in Nigerian waters has been mentioned (Offem et al. 2008).

Condition factor is an index of the degree of fatness or well being of a species (Bagenal $\&$ Tesch 1978). The study of condition factor is important to understand the life cycle of fish species, and contributes to an adequate management of the species and to the maintenance 
of the ecosystem equilibrium (Haruna \& Bichi 2005). Condition index may be used to determine the reproductive time of fish species without sacrificing the organisms, and this could be a valuable tool to develop monitoring programs for the species fisheries and culture programs (Arellano-Martinez \& CeballosVazquez 2001).

The dietary habits of fish, based on stomach analyses, is widely used in fish ecology as an important method to investigate trophic relationships in aquatic communities (Fagbenro et al. 2000). Food and feeding habits of some species of Chrysichthys in Nigeria have been studied in Lagos Lagoon (Ikusemiju \& Olaniyan 1977), Oguta Lake (Nwadiaro \& Okorie 1987), River Ase (Idodo-Umeh 2002), River Ethiope (Oronsaye \& Nakpodia 2005), Cross River (Offem et al. 2008) and Kainji Lake (Yem et al. 2009). Ikusemiju \& Olaniyan (1977) reported differences in the food habits of three Chrysichthys species in Lekki Lagoon: $C$. walkeri fed mostly on insects, $C$. filamentosus on crustaceans and $C$. nigrodigitatus on molluscs. The authors opined that the observed differences in feeding habits might be due to an active response to interspecific competition. Nwadiaro \& Okorie (1987) reported chaoborid and chironomid larvae, ostracods, copepods and detritus as the food items of $C$. filamentosus and therefore regarded the fish as a benthic omnivore. The authors also observed that larger $C$. filamentosus fed mostly on the insect larvae and detritus, while smaller individuals consumed mostly microcrustacea. Also Idodo-Umeh (2002) reported that $C$. auratus, $C$. nigrodigitatus and $C$. furcatus were omnivorous bottom feeders. The author reported no remarkable seasonal difference in the various food items consumed, but however, reported differences in the feeding habits of different sized groups in $C$. auratus longifilis while in C. nigrodigitatus all the sized groups consumed mainly detritus. Ajah et al. (2006) reported that juveniles of $C$. nigrodigitatus were omnivorous, consuming $32 \%$ gastropods, $30 \%$ nematodes, $14 \%$ diatoms and $8 \%$ crustaceans while adults were planktotrophic consuming 23\% diatoms, 33\% Chlorophyceae and 22\% crustaceans. The occurrence of mud, sand, detritus, insect larvae and worms in the stomach contents of fish could be interpreted as bottom feeding because these items are abundant in the benthos (Idodo-Umeh 2003). However, the latter author opined that fishes are extremely mobile, showing extensive longitudinal, vertical and horizontal movements therefore the variety of food items present in the stomach of fishes often reflect trophic flexibility or opportunistic feeders as suggested by Warren (1993); the ability of fishes to switch from one diet to another depending on availability.

This study aims to give information on the condition factor and feeding habits of two bagrid catfishes ( $C$. nigrodigitatus and $C$. auratus) of Aiba Reservoir, Iwo, thereby adding to the existing knowledge of the biology of both species.

\section{MATERIALS AND METHODS}

Aiba Reservoir $\left(07^{\circ} 38^{\prime}-07^{\circ} 39^{\prime}\right.$ N $004^{\circ} 11^{\prime}-004^{\circ} 13^{\prime}$ E), a small tropical man-made reservoir, lies in the Southwestern part of Nigeria. The dry season extends from November to March while the wet season is from April to October. Fish specimens (Chrysichthys nigrodigitatus and $C$. auratus) were collected from the reservoir between April 2005 and April 2006 using gill nets with mesh sizes between $25 \mathrm{~mm}$ and $30 \mathrm{~mm}$. Specimens were procured monthly from daily catch of artisanal fishermen using wooden canoes at landing points and taken to the laboratory. The fish specimens were identified using Reed et al. (1967), Olaosebikan \& Raji (1988), IdodoUmeh (2003). Measurement of standard length was taken on the left side of the fish with a ruled board to the nearest $0.1 \mathrm{~cm}$ and weighed fresh using a digital balance (Adam Model AAA 250L) to the nearest $0.1 \mathrm{~g}$. Dissection was carried out using stainless steel scissors and forceps; the guts were removed and preserved in 5\% formalin until the contents were analyzed. Both species are preserved in the 
Department of Biological Sciences laboratory, Bowen University, Iwo, Osun State, Nigeria.

As a result of the large length range, condition factor was calculated using $\mathrm{K}^{\prime}=100 \mathrm{~W} / \mathrm{L}^{\mathrm{b}}$ (Bagenal \& Tesch 1978), where K'=condition factor, $\mathrm{W}=$ Total weight (g), L=Standard length (cm) and $\mathrm{b}=$ regression (growth) coefficient. The stomach contents were observed and food items were identified to the lowest possible taxon under low power magnification of the microscope using Jeje \& Fernando (1986), and APHA, AWWA, WEF (1995). The frequency of occurrence and percentage composition by number methods according to Windell \& Bowen (1978) were adopted in the stomach content analysis. Gut repletion index (GRI) was calculated by dividing the number of empty guts by the total number of guts examined multiplied by 100 (Hyslop 1980). Diet breath is a measure of the food spectrum and was calculated using the Shannon-Wierner's diversity index $(\mathrm{H}): \mathrm{H}=-\Sigma \mathrm{p} i \log _{2} \mathrm{p} i$, where $\mathrm{p} i$ is the proportion by number of the food item $i$ (Berg 1979). Food richness was calculated using Margalef's index (d): $d=(S-1) / \log N$, where $S$ is the number of species and $\mathrm{N}$ is the number of individual food items (Pielou 1969, Brower \& Zar 1979, Offem et al. 2008). Diet similarity among species and seasons was calculated using Schoener Overlap index (C) (Schoener 1970); Cxy=1-0.5 $\Sigma$ (pxi-pyi), where px $i$ and pyi are the proportions by number of prey item $i$ in the diets of groups $\mathrm{x}$ and $\mathrm{y}$ (species or seasons) respectively. If the $\mathrm{C}$ value is greater than 0.80 , then the diet of the two groups is similar. Chi-square $\left(\chi^{2}\right)$ analysis was used to test for significant differences between the annual sex ratio of each species. Student t-test was used to determine significant differences in food items of the sexes of each species.

\section{RESULTS}

Size and sex ratio: $C$. nigrodigitatus recorded maximum standard length and weight of $25.6 \mathrm{~cm}$ and $288.7 \mathrm{~g}$ respectively, while $C$. auratus recorded maximum standard length and weight of $19.8 \mathrm{~cm}$ and $131 \mathrm{~g}$ respectively (Table 1). The mean weight and standard length for $C$. nigrodigitatus and $C$. auratus were $(74.9 \pm 6.2 \mathrm{~g}$ and $15.5 \pm 0.4 \mathrm{~cm}, 66.3 \pm 4.1 \mathrm{~g}$ and $14.7 \pm 0.5 \mathrm{~cm}$, respectively). Both species recorded similar mean weights and standard lengths for sex. The overall male to female ratio of $C$. nigrodigitatus (1:0.87) were similar ( $>>0.05)$ while that of $C$. auratus (1:0.38) were significantly different $(\mathrm{p}<0.001)$.

Condition factor: The lowest mean monthly condition factor for males $(3.03 \pm 0.11)$ and females $(2.76 \pm 0.00)$ of $C$. nigrodigitatus were recorded in June and February, respectively.

TABLE 1

Chi-square $\left(\chi^{2}\right)$ analysis of male to female sex-ratio; mean and overall range for weight and standard length of Chrysichthys nigrodigitatus and C.auratus

\begin{tabular}{|c|c|c|c|c|c|}
\hline \multicolumn{6}{|c|}{ Chrysichthys nigrodigitatus } \\
\hline & $\begin{array}{c}\text { Male }(n=39) \\
\text { Mean } \pm \text { Standard Error }\end{array}$ & $\begin{array}{c}\text { Female }(n=34) \\
\text { Mean } \pm \text { Standard Error }\end{array}$ & $\begin{array}{l}\text { Combined sexes }(n=73) \\
\text { Mean } \pm \text { Standard Error }\end{array}$ & Range & $\chi^{2}$ \\
\hline Weight $(\mathrm{g})$ & $75.5 \pm 8.8$ & $74.1 \pm 8.8$ & $74.9 \pm 6.2$ & $18.1-288.7$ & 0.34 \\
\hline Standard length (cm) & $15.5 \pm 0.6$ & $15.5 \pm 0.6$ & $15.5 \pm 0.4$ & $9.8-25.6$ & \\
\hline \multicolumn{6}{|c|}{ Chrysichthys auratus } \\
\hline & $\begin{array}{c}\text { Male }(n=39) \\
\text { Mean } \pm \text { Standard Error }\end{array}$ & $\begin{array}{c}\text { Female }(n=34) \\
\text { Mean } \pm \text { Standard Error }\end{array}$ & $\begin{array}{l}\text { Combined sexes }(n=73) \\
\text { Mean } \pm \text { Standard Error }\end{array}$ & Range & $\chi^{2}$ \\
\hline Weight $(g)$ & $66.1 \pm 5.0$ & $66.8 \pm 7.1$ & $66.3 \pm 4.1$ & $13.9-131.0$ & $11.66^{* * *}$ \\
\hline Standard length $(\mathrm{cm})$ & $14.4 \pm 0.4$ & $14.7 \pm 0.5$ & $14.7 \pm 0.5$ & $8.9-19.8$ & \\
\hline
\end{tabular}


However, the highest mean monthly condition factor for both sexes occurred in September (Fig. 1a). Generally the condition factor for both sexes decreased towards June and gradually rose to a peak in September. Males were better conditioned than females. The lowest mean monthly condition factor for male $C$. auratus $(1.87 \pm 0.08)$ was recorded in June while the highest $(2.20 \pm 0.15)$ was recorded in September; however, the lowest mean monthly condition factor for females $(2.03 \pm 0.06)$ was recorded in April, followed closely by June $(2.04 \pm 0.00)$, while the highest $(2.87 \pm 0.00)$ was recorded in February (Fig. 1b). Condition factor for both sexes decreased towards March, gradually increased to a peak in May and declined again towards June. Females were better conditioned compared to the males. Male $C$. nigrodigitatus and female C. auratus recorded significantly higher mean condition factors $\left(\mathrm{t}_{37}=-2.20, \mathrm{p}=0.034\right.$ and $\mathrm{t}_{14}=-2.17$, $\mathrm{p}=0.047$, respectively) during the dry season, compared to the wet season; however there was no significant seasonal difference $(\mathrm{p}>0.05)$ for the opposite sex and for sex combined (Fig. 1). $C$. nigrodigitatus was better conditioned than C. auratus (Fig. 2).

Food items: The food composition of C. nigrodigitatus and $C$. auratus included 12 species belonging to five groups: 3 species of Insecta, 5 species of Crustacea, 1 Arachnida, 1 Rotifera and 2 species of Mollusca (Table 2). Other food items were fish scales,
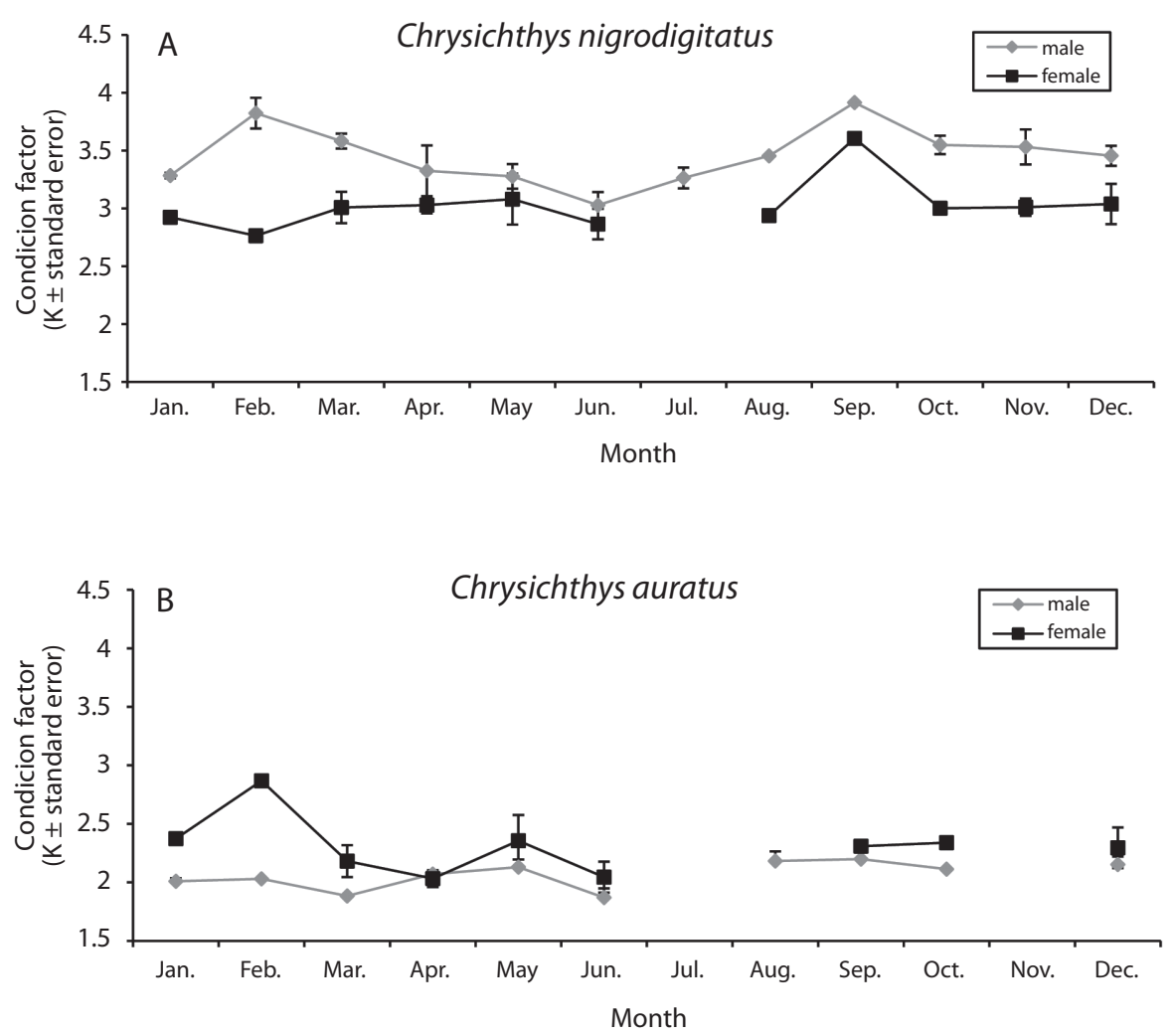

Fig. 1. Mean monthly condition factor of male and female of (a) Chrysichthys nigrodigitatus and (b) C. auratus in Aiba Reservoir. 


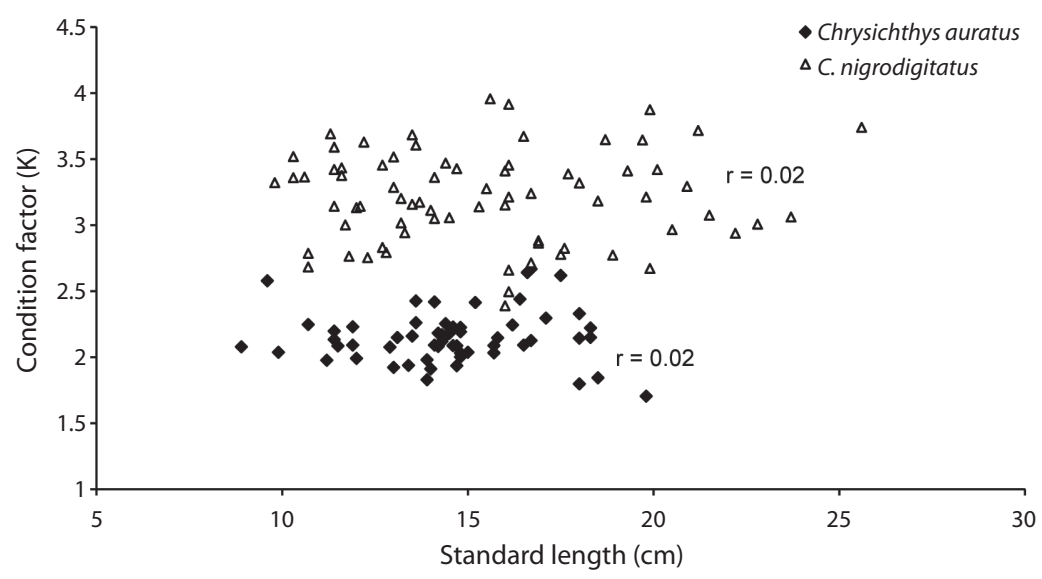

Fig. 2. Relationship between condition factor and standard length of Chrysichthys nigrodigitatus and C. auratus.

TABLE 2

Occurrence and numerical abundance of food items found in both sexes of Chrysichthys nigrodigitatus and C. auratus stomachs

\begin{tabular}{|c|c|c|c|c|c|c|c|c|}
\hline \multirow{3}{*}{ FOOD ITEMS } & \multicolumn{4}{|c|}{ Occurrence $(\%)^{\mathrm{a}}$} & \multicolumn{4}{|c|}{ Numerical abundance $(\%)^{a}$} \\
\hline & \multicolumn{2}{|c|}{$\begin{array}{l}\text { Chrysichthys } \\
\text { nigrodigitatus }\end{array}$} & \multicolumn{2}{|c|}{$\begin{array}{c}\text { Chrysichthys } \\
\text { auratus }\end{array}$} & \multicolumn{2}{|c|}{$\begin{array}{l}\text { Chrysichthys } \\
\text { nigrodigitatus }\end{array}$} & \multicolumn{2}{|c|}{$\begin{array}{c}\text { Chrysichthys } \\
\text { auratus }\end{array}$} \\
\hline & MALE & FEMALE & MALE & FEMALE & MALE & FEMALE & MALE & FEMALE \\
\hline Brachionus & 6.90 & 3.85 & 3.33 & 6.67 & 0.09 & 0.02 & 0.02 & 0.04 \\
\hline ROTIFERA & 6.90 & $3.85(5.45)$ & 3.33 & $6.67(4.44)$ & 0.09 & $0.02(0.06)$ & 0.02 & $0.04(0.02)$ \\
\hline Melanoides & 0.00 & 3.85 & 0.00 & 13.33 & 0.00 & 0.17 & 0.00 & 0.18 \\
\hline Bulinus & 0.00 & 3.85 & 0.00 & 0.00 & 0.00 & 0.04 & 0.00 & 0.00 \\
\hline MOLLUSCA & 0.00 & $3.85(1.82)$ & 0.00 & $13.33(4.44)$ & 0.00 & $0.22(0.09)$ & 0.00 & $0.18(0.06)$ \\
\hline Hydracarina & 0.00 & 3.85 & 3.33 & 0.00 & 0.00 & 0.02 & 0.02 & 0.00 \\
\hline ARACHNIDA & 0.00 & $3.85(1.82)$ & 3.33 & $0.00(4.44)$ & 0.00 & $0.02(0.01)$ & 0.02 & $0.00(0.01)$ \\
\hline Mesocyclops & 86.21 & 84.62 & 73.33 & 80.00 & 27.66 & 16.97 & 36.93 & 6.98 \\
\hline Thermodiaptomus & 6.90 & 3.85 & 16.67 & 0.00 & 0.19 & 0.02 & 0.64 & 0.00 \\
\hline Diaphanosoma & 37.93 & 34.62 & $40.00 *$ & 20.00 & 18.45 & 8.61 & 26.49 & 0.14 \\
\hline Alona & 3.45 & 0.00 & 0.00 & 6.67 & 0.07 & 0.00 & 0.00 & 0.11 \\
\hline Ostracod & 13.79 & 19.23 & 20.00 & 33.33 & 0.93 & 8.29 & 0.73 & 25.90 \\
\hline CRUSTACEA & 86.21 & $92.31(89.09)$ & 73.33 & $86.67(77.78)$ & 47.30 & $33.89(41.92)$ & 64.78 & $33.13(54.69)$ \\
\hline Chaoborus & 55.17 & 57.69 & 43.33 & 53.33 & 3.03 & 17.51 & 5.69 & 1.05 \\
\hline Chironomus & 48.28 & 38.46 & 33.33 & 73.33 & 48.48 & 42.66 & 26.35 & 64.30 \\
\hline Povilla & 27.59 & 26.92 & 16.67 & 33.33 & 0.78 & 3.06 & 0.47 & 1.30 \\
\hline INSECTA & 75.86 & $80.77(78.18)$ & 60.00 & $80.00(66.67)$ & 52.30 & $63.22(56.68)$ & 32.51 & $66.65(43.39)$ \\
\hline Fish scale & 6.90 & 0.00 & 3.33 & 0.00 & 0.17 & 0.00 & 2.64 & 0.00 \\
\hline Unidentif. green eggs & 3.45 & 15.38 & 3.33 & 0.00 & 0.15 & 2.63 & 0.02 & 0.00 \\
\hline Seed & 0.00 & 0.00 & 3.33 & 0.00 & 0.00 & 0.00 & 0.02 & 0.00 \\
\hline Macrophyte & 27.59 & 26.92 & 10.00 & 33.33 & & & & \\
\hline Detritus & 37.93 & 34.62 & 20.00 & 26.67 & & & & \\
\hline Sand & 48.28 & 38.46 & 20.00 & 46.67 & & & & \\
\hline OTHERS & 72.41 & $69.23(70.91)$ & 36.67 & $46.67(40.00)$ & 0.32 & $2.63(1.24)$ & 2.67 & $0.00(1.82)$ \\
\hline
\end{tabular}

${ }^{\mathrm{a}}=$ average value for both sexes in parenthesis. ${ }^{*}=$ significant at $\mathrm{p} \leq 0.05$. 
unidentified green eggs, seeds, macrophyte parts, detritus and sand. For C. nigrodigitatus and $C$. auratus, Crustacea occurrence in stomach contents constitute $89.09 \%$ and $77.78 \%$, followed by Insecta, with $78.18 \%$ and $66.67 \%$ respectively. Other food items especially macrophytes, detritus and sand recorded high percentage occurrence, with $C$. nigrodigitatus $(70.91 \%)$ recording a higher occurrence compared to $C$. auratus $(40.00 \%)$. Crustacea and Insecta occurred more in the diet of female C. nigrodigitatus $(92.31 \%$ and $80.77 \%$ respectively) and female $C$. auratus $(86.67 \%$ and $80.00 \%$ respectively) compared to males. Male of $C$. auratus recorded a significantly higher $(\mathrm{p}<0.05)$ percentage occurrence $(40.00 \%)$ of Diaphanosoma compared to females (20.00\%). Melanoides was absent in the diet of males of both species, however, Bulinus was recorded only from the diet of female $C$. nigrodigitatus. Hydracarina was absent only in the diet of male $C$. nigrodigitatus and female $C$. auratus. Fish scales were only recorded in males of both species, and seeds were solely recorded from the stomachs of male $C$. auratus.

In terms of numerical abundance, Insecta dominated as prey items in the diet of $C$. nigrodigitatus $(56.68 \%$ ) followed by Crustacea (41.92\%); while Crustacea (54.69\%) dominated the diet of $C$. auratus followed by Insecta $(43.39 \%)$. Insecta was numerically more abundant in the diet of female C. auratus $(66.65 \%)$ than in males $(32.51 \%)$, while Crustacea were numerically more abundant in the diet of male C. auratus $(64.78 \%)$ than in females $(33.13 \%)$. Thermodiaptomus was more abundant in the diet of males of both species, while ostracods recorded higher numerical abundance as a food item in females of both species. Mollusca, Arachnida and Rotifera accounted for less than $0.2 \%$ numerical abundance as food items.

Insecta, especially Chaoborus and Chironomus, dominated the stomach contents of both species during the dry season compared to the wet, in terms of occurrence and numerical abundance (Table 3). Chaoborus recorded a significantly higher occurrence $(\mathrm{p}<0.05)$ in the stomach contents of $C$. nigrodigitatus during the dry season $(85.71 \%)$ compared to the wet season $(25.93 \%)$. Other food items, especially detritus and sand, occurred more during the dry season for both species. Thermodiaptomus and Diaphanosoma were numerically more abundant during the dry and wet seasons respectively for both species of fish. Hydracarina, Brachionus and unidentified green eggs were numerically more abundant in the diet of both species during the wet season, while Mollusca were more abundant in the diet of both species during the dry season.

Insecta increased numerically with the increase in size of fish (from $10.41 \%$ to $94.11 \%$ ), while Crustacea decreased (from $89.59 \%$ to $1.58 \%$ ) with increase in fish size of $C$. nigrodigitatus (Fig. 3a). However, for $C$. auratus, Crustacea $(98.72 \%$ ) dominated as food items numerically in the diet of $8.1 \mathrm{~cm}-12.0 \mathrm{~cm}$ size class while Insecta (1.28\%) recorded the least (Fig. 3b). Other food items showed a steady increase with increase in fish size from $0.00 \%(8.1 \mathrm{~cm}-12.0 \mathrm{~cm})$ to $4.27 \%(20.1 \mathrm{~cm}-$ $26.0 \mathrm{~cm}$ ) for $C$. nigrodigitatus. However, for $C$. auratus, Rotifera and other food items showed a slight increase $(0.00 \%$ to $0.04 \%$ and $0.00 \%$ to $2.13 \%$ respectively) with increase in fish size (from $8.1 \mathrm{~cm}-12.0 \mathrm{~cm}$ to $16.1 \mathrm{~cm}-20.0 \mathrm{~cm}$ size classes).

Schoener Overlap Index for both species and between seasons is 1.00 . Diet breadth ranged from $0.00-1.47$ for $C$. nigrodigitatus and 0.00-1.32 for C. auratus (Table 4). Lower breadth was recorded for females of both species compared to the males, and during the wet season for $C$. auratus. Food Richness ranged from 0.00-1.44 for both species. Lower richness was, however, recorded for female $C$. nigrodigitatus compared to males; and during the dry season compared to the wet for both species.

The overall Gut Repletion Index recorded for $C$. nigrodigitatus and $C$. auratus are $76.39 \%$ and $76.27 \%$, respectively. However, while the Gut Repletion Index for both sexes and both seasons are similar for $C$. nigrodigitatus, female $C$. auratus fed more (93.75\%) compared to the males $(69.77 \%)$ and both sexes 
TABLE 3

Occurrence and numerical abundance of food items found by season in Chrysichthys nigrodigitatus and C.auratus stomachs

\begin{tabular}{|c|c|c|c|c|c|c|c|c|}
\hline \multirow{3}{*}{ FOOD ITEMS } & \multicolumn{4}{|c|}{ Occurrence $(\%)$} & \multicolumn{4}{|c|}{ Numerical abundance (\%) } \\
\hline & \multicolumn{2}{|c|}{$\begin{array}{l}\text { Chrysichthys } \\
\text { nigrodigitatus }\end{array}$} & \multicolumn{2}{|c|}{$\begin{array}{c}\text { Chrysichthys } \\
\text { auratus }\end{array}$} & \multicolumn{2}{|c|}{$\begin{array}{l}\text { Chrysichthys } \\
\text { nigrodigitatus }\end{array}$} & \multicolumn{2}{|c|}{$\begin{array}{c}\text { Chrysichthys } \\
\text { auratus }\end{array}$} \\
\hline & WET & DRY & WET & DRY & WET & DRY & WET & DRY \\
\hline Brachionus & 11.11 & 0.00 & 6.45 & 0.00 & 0.12 & 0.00 & 0.03 & 0.00 \\
\hline ROTIFERA & 11.11 & 0.00 & 6.45 & 0.00 & 0.12 & 0.00 & 0.03 & 0.00 \\
\hline Melanoides & 0.00 & 3.57 & 0.00 & 14.29 & 0.00 & 0.14 & 0.00 & 0.20 \\
\hline Bulinus & 0.00 & 3.57 & 0.00 & 0.00 & 0.00 & 0.04 & 0.00 & 0.00 \\
\hline MOLLUSCA & 0.00 & 3.57 & 0.00 & 14.29 & 0.00 & 0.18 & 0.00 & 0.20 \\
\hline Hydracarina & 3.70 & 0.00 & 3.23 & 0.00 & 0.02 & 0.00 & 0.02 & 0.00 \\
\hline ARACHNIDA & 3.70 & 0.00 & 3.23 & 0.00 & 0.02 & 0.00 & 0.02 & 0.00 \\
\hline Mesocyclops & 85.19 & 85.71 & 67.74 & 92.86 & 25.73 & 20.96 & 26.57 & 29.45 \\
\hline Thermodiaptomus & 0.00 & 10.71 & 3.23 & 28.57 & 0.00 & 0.25 & 0.08 & 1.35 \\
\hline Diaphanosoma & 33.33 & 39.29 & 32.26 & 35.71 & 26.49 & 2.25 & 24.61 & 1.55 \\
\hline Alona & 3.70 & 0.00 & 0.00 & 7.14 & 0.09 & 0.00 & 0.00 & 0.12 \\
\hline Ostracod & 29.63 & 3.57 & 29.03 & 14.29 & 7.63 & 0.04 & 5.88 & 16.03 \\
\hline CRUSTACEA & 88.89 & 89.29 & 70.97 & 92.86 & 59.94 & 23.49 & 57.14 & 48.49 \\
\hline Chaoborus & 25.93 & $85.71 *$ & 32.26 & 78.57 & 6.62 & 11.10 & 3.50 & 6.00 \\
\hline Chironomus & 40.74 & 46.43 & 32.26 & 78.57 & 28.71 & 63.99 & 36.34 & 43.80 \\
\hline Povilla & 33.33 & 21.43 & 19.35 & 28.57 & 2.34 & 1.04 & 0.45 & 1.47 \\
\hline INSECTA & 59.26 & 96.43 & 54.84 & 92.86 & 37.67 & 76.12 & 40.29 & 51.26 \\
\hline Fish scale & 0.00 & 7.14 & 0.00 & 7.14 & 0.00 & 0.21 & 0.00 & 0.04 \\
\hline Green eggs & 18.52 & 0.00 & 3.23 & 0.00 & 2.25 & 0.00 & 2.51 & 0.00 \\
\hline Seed & 0.00 & 0.00 & 3.23 & 0.00 & 0.00 & 0.00 & 0.02 & 0.00 \\
\hline Macrophyte & 29.63 & 25.00 & 12.90 & 28.57 & & & & \\
\hline Detritus & 25.93 & 46.43 & 19.35 & 28.57 & & & & \\
\hline Sand & 29.63 & 57.14 & 19.35 & 50.00 & & & & \\
\hline OTHERS & 51.85 & 89.29 & 32.26 & 57.14 & 2.25 & 0.21 & 2.52 & 0.04 \\
\hline
\end{tabular}

$*=$ significant at $\mathrm{p} \leq 0.05$.

TABLE 4

Diet breadth, food richness and Gut Repletion Index (GRI)

of Chrysichthys nigrodigitatus and C.auratus by sex and season

\begin{tabular}{lcccccc} 
& \multicolumn{2}{c}{ Diet breadth } & \multicolumn{2}{c}{ Food richness } & \multicolumn{2}{c}{ Gut Repletion Index (\%) } \\
& $\begin{array}{l}\text { Chrysichthys } \\
\text { nigrodigitatus }\end{array}$ & $\begin{array}{c}\text { Chrysichthys } \\
\text { auratus }\end{array}$ & $\begin{array}{c}\text { Chrysichthys } \\
\text { nigrodigitatus }\end{array}$ & $\begin{array}{c}\text { Chrysichthys } \\
\text { auratus }\end{array}$ & $\begin{array}{c}\text { Chrysichthys } \\
\text { nigrodigitatus }\end{array}$ & $\begin{array}{c}\text { Chrysichthys } \\
\text { auratus }\end{array}$ \\
Male & $0.06-1.47$ & $0.00-1.32$ & 76.32 & 69.77 & $0.16-1.44$ & $0.00-1.20$ \\
Female & $0.00-1.11$ & $0.00-0.98$ & 76.47 & 93.75 & $0.00-0.67$ & $0.00-1.44$ \\
Wet season & $0.00-1.47$ & $0.00-0.97$ & 75.00 & 81.58 & $0.00-1.44$ & $0.00-1.44$ \\
Dry season & $0.06-1.46$ & $0.00-1.32$ & 77.78 & 66.67 & $0.16-1.13$ & $0.00-1.20$ \\
Total & $0.00-1.47$ & $0.00-1.32$ & 76.39 & 76.27 & $0.00-1.44$ & $0.00-1.44$
\end{tabular}


A Chrysichthys nigrodigitatus
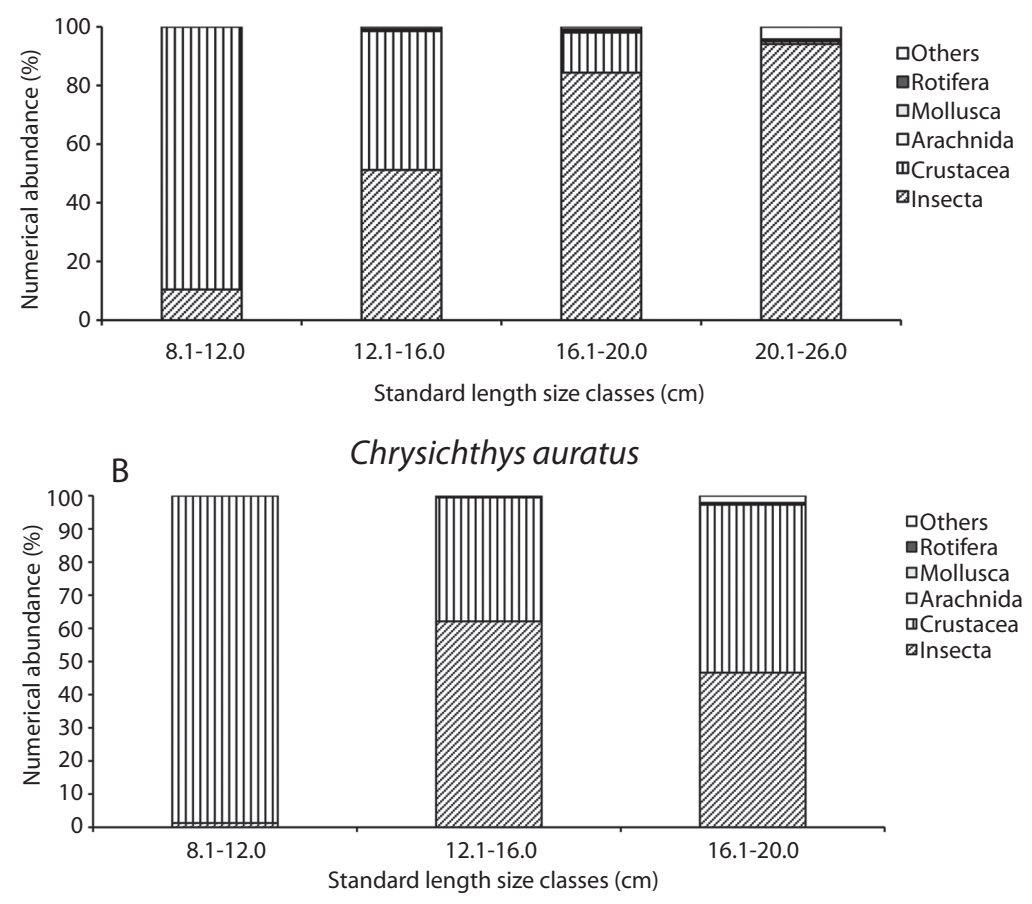

Fig. 3. Percentage numerical abundance of major groups of food items in the stomachs of different size classes of Chrysichthys nigrodigitatus and C. auratus.

of the same species recorded more non-empty stomach during the wet season $(81.58 \%)$ compared to the dry $(66.67 \%)$.

\section{DISCUSSION}

Size and sex ratio: Maximum standard length of $25.6 \mathrm{~cm}$ and a weight of $288.7 \mathrm{~g}$ recorded for $C$. nigrodigitatus and maximum standard length of $19.8 \mathrm{~cm}$ and a weight of $131 \mathrm{~g}$ recorded for C. auratus in Aiba Reservoir are lower than maximum sizes of same species recorded from River Ase in Delta State ( $\mathrm{SL}=57.5 \mathrm{~cm}$, weight $=1500 \mathrm{~g}$ for $C$. nigrodigi tatus; $\mathrm{SL}=33 \mathrm{~cm}$, weight $=272 \mathrm{~g}$ for $C$. aura tus) and River Niger (SL $=57 \mathrm{~cm}$, weight $=1$ $810 \mathrm{~g}$ for C. auratus) (Idodo-Umeh 2003). The mean sizes recorded for $C$. nigrodigitatus and C. auratus from Aiba Reservoir $(15.5 \pm 0.4 \mathrm{~cm}$ and $14.7 \pm 0.5 \mathrm{~cm}$, respectively) suggests that intensive fishing activity had impacted negatively on fish size as they are not allowed to grow to maximum size. Offem et al. (2008) reported size at maturity for males and females of Chrysichthys nigrodigitatus as $11.5 \mathrm{~cm}$ and $16.7 \mathrm{~cm}$ total length. This may suggest that the species are threatened. The annual sex ratios for $C$. nigrodigitatus were similar while that of $C$. auratus were significantly different indicating spatial separation of both species and reproductive strategy for $C$. auratus. Offem et al. (2008) observed male dominance of $C$. nigrodigitatus in the Cross River and attributed this to the fact that the gears used were not set close to the breeding ground as males possibly emigrate from spawning areas to feeding grounds located in shallow part of the water body where they were captured. The 
authors also suggested that the females could go towards submerged vegetation and rocky areas to avoid fishermen and carry out incubation and protection of offspring.

Condition factor: $C$. nigrodigitatus were better conditioned compared to $C$. auratus. The males of $C$. nigrodigitatus and females of $C$. auratus were generally better conditioned than their respective opposite sex. This suggests intra-specific variation with regards to sex in the condition of each species. The lowest condition factor recorded in June for both species may suggest that June is the peak spawning month. Females of $C$. auratus also recorded a low condition factor in April suggesting two breeding periods; April and June which disagrees with Idodo-Umeh (2003) who reported that $C$. nigrodigitatus breeds between July and October. Low condition factor values are recorded when environmental conditions are poor and by spawning pressure in females (Haruna \& Bichi 2005). Inverse relationship between reproductive activity and condition factor has been reported for both sexes of the fish species, Holocanthus passer (ArellanoMartinez \& Ceballos-Vazquez 2001). Adedeji \& Araoye (2006) attributed the slightly better condition of female Synodontis schall to differences in energy expended on egg and milt production. The low condition factor recorded for $C$. nigrodigitatus after the second peak in September and October; and in October for $C$. auratus may be due to reduced availability of food and prey items.

Feeding habits: Chrysichthys species are regarded as omnivorous detritivores (Oronsaye \& Nakpodia 2005, Offem et al. 2008 and Yem et al. 2009). The morphology of Chrysichthys is adapted for bottom feeding although stomach contents may prove otherwise as the variety of food items contained in the stomach of fishes often reflect the ability of fishes to obtain food from different locations. Morphological features, therefore cannot limit Chrysichthys as exclusive bottom feeders (Idodo-Umeh 2003). The food items of both sexes of $C$. nigrodigitatus and C. auratus were similar, with Crustacea and Insecta dominating in terms of percentage occurrence and numerical abundance, followed in order by sand, detritus and macrophyte in terms of percentage occurrence. Both species may therefore be regarded as generalist mesopredators. $C$. nigrodigitatus has been reported to feed mainly on adult molluscs and crustaceans in Lagos Lagoon (Ikusemiju \& Olaniyan 1977), it is also regarded as a carnivore that feeds throughout the water column (Ajani 2001). The presence of fish scales in fish could be due to scale eating habits. This is in agreement with studies by (Idodo-Umeh 2003) on some specialized predators in tropical communities. However, the author cautioned that evidence available from the examination of the stomach contents is not conclusive as prey fish and fish remains from the substratum could also account for the presence of fish scales in stomach contents. The inclusion of sand grains in the stomach of fish has been attributed as an accidental ingestion along with other food items (Fagbenro et al. 2000). Idodo-Umeh (2003) reported that $C$. nigrodigitatus and $C$. auratus could be considered as bottom feeding mesopredators in River Ase, Delta State, although he opined that they can easily fit into the omnivorous category.

The similarity in the utilization of food items by both species, as shown by a Schoener Overlap Index of 1.00, suggests interspecific competition; since diet overlap is highly significant (Schoener index $>0.60$ ). Oso et al. (2006) reported interspecific competition between Oreochromis niloticus and Sarotherodon galilaeus in Ero Reservoir, Ekiti State. The authors, however, opined that the similarity in ecological niche was already accompanied by some discrete differences in the selection of complementary food items. Differences in the abundance and occurrence of food items between sexes suggest strategies to reduce intra-specific competition. The males of $C$. nigrodigitatus fed more on planktonic crustaceans while the females fed more on benthic insect larvae. Differences in the abundance of food items of C. nigrodigitatus between seasons may be as a 
result of the seasonal availability of food items, as Chaoborus recorded a significant higher occurence during the dry season. This may be due to the fact that Chaoborus larvae are better exposed to predation as a result of reduced water level, low turbidity and increased penetration of light into the reservoir. The significant higher occurrence of Diaphanosoma as a food item in male $C$. auratus in addition to the occurrence of Melanoides only in females suggest that the sexes occupy relatively different positions in the water column with the females feeding on the benthic portion of the reservoir while the males fed in the open waters of the pelagic region. The spatial separation of $C$. auratus in terms of feeding habit also attests to the fact that fewer females were caught with gill nets.

Differences in the abundance and occurrence of food items with size classes for $C$. nigrodigitatus shows that the insects are preferred to the crustaceans which are relatively smaller organisms as the fish grows in size. There was preference for Chironomus and Chaoborus by larger sized fish compared to Mesocyclops and Diaphanosoma by smaller sized fish. This pattern was slightly different for $C$. auratus as crustaceans dominated the diet of small sized fish especially Mesocyclops and Diaphanosoma while as the fish increased in size Chironomus larva increased in their diet in addition to the dominant crustaceans. For both species there were slight increases in the occurrence and abundance of other food items apart from insects and crustaceans. This suggests that both species became less specialized mesopredators with increase in size.

Idodo-Umeh (2002) reported no remarkable difference in the various food items between seasons but reported differences in feeding habits of different size groups in $C$. auratus longifilis while in $C$. nigrodigitatus all the size groups consumed mainly detritus. Fawole (2002) reported that sex, season and size did not affect the feeding habits of $M$. rume. Idowu \& Ugwumba (2006) reported higher seasonal feeding intensity of Hepsetus odoe in Ado-Ekiti Reservoir during the rainy season for females and vice-versa for the males. This was attributed to the fact that females require more food for their reproductive activities which was observed to be at its peak during the rainy season in the reservoir. They also reported that size did not play a significant role in feeding intensity.

The high Gut Repletion Index recorded for both species suggests that both species feed frequently. Offem et al. (2009) opined that uniformity in the Gut Repletion index for different species seem to be a strategy that culminates in similar growth rates and breeding season for such species. The wider Diet Breadth recorded by males of both species compared to females; and by $C$. nigrodigitatus compared to $C$. auratus during the dry season shows higher trophic flexibility. This may suggest that males of both species could easily switch from one category of food to another in response to fluctuation in prey abundance and that $C$. nigrodigitatus was better at exploiting prey items during the wet season. The higher range of food richness recorded by male $C$. nigrodigitatus compared to females and by female $C$. auratus compared to males strongly supports the data on condition factors for both species. The higher range of food richness recorded by both species during the wet compared to the dry season supports the fact that both species fed on a greater variety of food items during this period (Hydracarina, Brachionus and unidentified green eggs during the wet compared to only Melanoides during the dry season).

This study suggests intraspecific variation in the condition of both species with regards to sex. It also shows similarity and overlaps in the utilization of food items by these threatened species, although there were seasonal, sex and size variations in feeding habits. Crustacea and Insecta dominated the food items of both species in terms of percentage occurrence and numerical abundance. There are, however, discrete differences in the selection of supplementary food items. Both species have consequently evolved strategies to cope with inter- and intraspecific competition. The strategies include exploitation competition, spatial separation in 
the reservoir and variation in the utilization of food items by different size groups.

\section{RESUMEN}

Chrysichthys nigrodigitatus y $C$. auratus son dos especies importantes de peces de agua dulce, de gran valor y amenazadas. Para contribuir con sus conocimientos ecológicos, se estudió el factor de condición y la dieta de estas dos especies congenéricas entre abril de 2005 y abril de 2006. Las categorías alimentarias fueron evaluadas por presencia y métodos de abundancia numérica, y los posibles cambios entre sexos, estaciones y tamaños fueron considerados. Los resultados mostraron que, en general los individuos de $C$. nigrodigitatus fueron estan en mejores condiciones que los individuos de C. auratus. Los machos de C. nigrodigitatus y las hembras de C.auratus se encontraban en mejores condiciones que su respectivo sexo opuesto durante todo el año, y durante la estación lluviosa en comparación con la seca. Las categorías alimentarias de $C$. nigrodigitatus y $C$. auratus fueron similares y se compone por 12 especies pertenecientes a cinco grupos: Insecta (tres especies), Crustacea (cinco especies), Arachnida (una especie), Rotifera (una especie) y Mollusca (dos especies). Otras categorías alimentarias incluyen escamas de peces, huevos verdes sin identificar, partes de plantas, detritos y arena. Insecta y Crustacea dominaron las categorías alimentarias en ambas especies. Para C. nigrodigitatus, el consumo de insectos incrementa con el tamaño del pez, mientras los crustáceos disminuyeron (de $89.59 \%$ para $8.1 \mathrm{~cm}$ - clase de tamaño $12.0 \mathrm{~cm}$ a $1.58 \%$ para $20.1 \mathrm{~cm}$ clase de tamaño $26.0 \mathrm{~cm}$ ). Sin embargo, mientras que los peces más pequeños de $C$. auratus tiene preferencia por Crustacea (98.72\% para $8.1 \mathrm{~cm}-12.0 \mathrm{~cm}$ clase de tamaño), los peces más grandes de ambos grupos tienen cantidades relativamente similares. El índice Schoener de Superposición para ambas especies y entre las estaciones fue 1.00. La amplitud de la dieta varió desde 0.00-1.47 para $C$. nigrodigitatus, y 0.00-1.32 para C. auratus. La riqueza de la alimentación varió desde 0.00-1.44 para ambas especies. El índice Gut Repletion para C. nigrodigitatus y C.auratus fue $76.39 \%$ y $76.27 \%$, respectivamente. Aunque, existe similitud y un traslapo considerable en la utilización de los recursos alimenticios en ambas especies coexistentes, el factor de condición y el comportamiento de alimentación sugieren estrategias para reducir la competencia intra- e inter-especifica.

Palabras clave: Chrysichthys, factor de condición, conducta alimentaria, competición, Reserva Aiba.

\section{REFERENCES}

Adedeji, R.A. \& P.A. Araoye. 2006. Study and characterization in the growth of body parts of Synodontis schall (Pisces: Mochokidea) from Asa Dam, Ilorin, Nigeria. Nigerian J. Fisheries 2/3: 219-244.

Ajah, P.O., M.N. Georgewill \& M.O. Ajah. 2006. The food and feeding habits of five freshwater and brackishwater fish species in Nigeria. Afr. J. Aquat. Sci. 31: 313-318.

Ajani, E.K. 2001. Effects of biotic and abiotic components of the habitat on fish productivity in Lagos Lagoon, Nigeria. Ph.D. Thesis, University of Ibadan, Ibadan, Nigeria.

Akinsanya, B., O.A. Otubanjo \& C.A. Ibidapo. 2007. Helminth bioload of Chrysichthys nigrodigitatus (Lacepede 1802) from Lekki Lagoon, Lagos Nigeria. Turk. J. Fish. Aquat. Sci. 7: 83-87.

APHA, AWWA, WEF. 1995. Standard Methods for the Examination of Water and Wastewater. American Public Health Association, American Water Works Association, Water Environment Federation. Washington D.C., USA.

Arellano-Martinez, M. \& B.P. Ceballos-Vazquez. 2001. Reproductive activity and condition index of Holocanthus passer (Teleostei: Pomacanthidae) in the Gulf of California, Mexico. Rev. Biol. Trop. 49: 939-943.

Bagenal, T.B. \& F.W. Tesch. 1978. Age and growth, p. 101-136. In T.B. Bagenal (ed.). Methods for assessment of fish production in freshwaters. Blackwell, London, England.

Berg, J. 1979. Discussion of methods of investigating the food of fishes with reference to a prelimnary study of the prey Gobiusculus flavescens (Gobiidae). Mar. Biol. 50: 263-273.

Brower, J.E. \& J.H. Zar. 1979. Field and laboratory methods for general ecology. E.C. Brown, Dubuque, Iowa, USA.

Fagbenro, O., C.O. Adedire, E.O. Ayotunde \& E.O. Faminu. 2000. Haematological profile, food composition and digestive enzyme assay in the gut of the African bony tongue, Heterotis (Clupisudis) niloticus (Cuvier 1829) (Osteoglossidae). Trop. Zool. 13: 1-9.

Fawole, O.O. 2002. Morphometry and diet of Mormyrus rume in the Lekki Lagoon, Nigeria. Rev. Biol. Trop. 50: 689-694.

Haruna, M. \& A.H. Bichi. 2005. Studies on length-weight relationship and condition factor of the cichlids of Tomas Lake, Kano, Nigeria. Biol. Environ. Sci. J. Trop. 2: 94-100. 
Hyslop, E.J. 1980. Stomach content analysis: a review of methods and their application. J. Fish Biol. 17: 411-429.

Idodo-Umeh, G. 2002. The feeding ecology of bagrid species in River Ase, Niger Delta, southern Nigeria. Trop. Freshwater Biol. 11: 47-68.

Idodo-Umeh, G. 2003. Freshwater fishes of Nigeria (Taxonomy, ecological notes, diet and utilization). IdodoUmeh, Benin City, Edo State, Nigeria.

Idodo-Umeh, G. \& R. Victor. 1991. Some aspects of the ecology of bagrid catfishes in a southern Nigerian river. J. Trop. Ecol. 7: 221-232.

Idowu, E.O. \& A.A.A. Ugwumba. 2006. The food and feeding habits of African Pike, Hepsetus odoe (Bloch, 1974) (Osteichthyes: Hepsetidae) in Ado-Ekiti Reservoir, Nigeria. The Zoologist 4: 7-17.

Ikusemiju, K. \& C.I.O. Olaniyan. 1977. The food and feeding habits of the catfishes: Chrysichthys walkeri (Gunther), Chrysichthys filamentosus (Boulenger) and Chrysichthys nigrodigitatus (Lacépède) in the Lekki Lagoon, Nigeria. J. Fish Biol. 10: 105-112.

Jeje, C.Y. \& C.H. Fernando. 1986. A practical guide to the identification of Nigerian zooplankton (Cladocera, Copepoda and Rotifera) Kainji Lake. Research Institute, Niger, Nigeria.

Nwadiaro, C. \& P. Okorie. 1987. Feeding habits of the African bagrid, Chrysichthys filamentosus in a Nigerian lake. Ichthyol. Res. 33: 376-383.

Offem, B.O., Y. Akegbejo-Samsons \& I.T. Omoniyi. 2008. Diet, size and reproductive biology of the silver catfish, Chrysichthys nigrodigitatus (Siluriformes: Bagridae) in the Cross River, Nigeria. Rev. Biol. Trop. 56: 1785-1799.

Offem, B.O., Y. Akegbejo-Samsons \& I.T. Omoniyi. 2009 Trophic ecology of commercially important fishes in the Cross River, Nigeria. J. Anim. Plant Sci. 19: $37-44$.

Olaosebikan, B.D. \& A. Raji. 1988. Field guide to Nigerian freshwater fisheries. Federal College of freshwater
Fisheries Technology, New Bussa, Niger State, Nigeria.

Olarinmoye, O., V. Taiwo, E. Clarke, C. Kumolu-Johnson, O. Aderinola \& F. Adekunbi. 2009. Hepatic pathologies in the brackish water catfish (Chrysichthys nigrodigitatus) from contaminated locations of Lagos Lagoon complex. Appl. Ecol. Environ. Res. 7: $277-286$.

Oronsaye, C.G. \& F.A. Nakpodia. 2005. A comparative study of the food and feeding habits of Chrysichthys nigrodigitatus and Brycinus nurse in a tropical river. Pakistan J. Sci. Indust. Res. 48: 118-121.

Oso, J.A., I.A. Ayodele \& O. Fagbuaro. 2006. Food and feeding habits of Oreochromis niloticus (L.) and Sarotherodon galilaeus (L.) in a tropical reservoir. World J. Zool. 1: 118-121.

Pielou, E.C. 1969. An introduction to mathemathecal ecology. Wiley, New York, USA.

Reed, W., J.J. Burchard, A.J. Hopson \& I. Yaro. 1967. Fish and Fisheries of Northern Nigeria. Ministry of Agriculture, Northern Nigeria, Zaria, Nigeria.

Saliu, J.K. 2008. Effect of smoking and frozen storage on the nutrient composition of some African fish. Adv. Nat. Appl. Sci. 2: 16-20.

Schoener, T.W. 1970. Non-synchronous spatial overlap of lizards in patchy habitat. J. Ecol. 51: 408-418.

Warren, W.G. 1993. Changes in the within-survey spatial temporal structure of the Northern cod (Gadus morhua) population, 1985-1993. Can. J. Fish. Aquat. Sci. 54: $139-148$

Windell, J.T. \& S.H. Bowen. 1978. Methods for Study of Fish Diets Based on Analysis of Stomach Contents, p. 219-226. In T.B. Bagenal (ed.). Methods for Assessment of Fish Production in Freshwaters. Blackwell, London, England.

Yem, I.Y., N.O. Bankole, O. Ogunfowora \& B. Ibrahim. 2009. Food habit of the catfish Chrysichthys nigrodigitatus (Geoffrey Saint Hilaire, 1808) in Kainji Lake, Nigeria. Nat. Sci. 7: 17-22. 